\title{
How do foreign investors impact domestic economic activity? Evidence from China and India.
}

\author{
Chotibhak Jotikasthira, Christian Lundblad, and Tarun Ramadorai*
}

November 2012

\begin{abstract}
There has been renewed advocacy for restrictions on international financial flows in the wake of the recent financial crisis. Motivated by this trend, we explore the extent to which cross-border flows affect real economic activity. Unlike previous research efforts that focus on aggregated capital flows, we exploit novel data on forced trading by global mutual funds as a plausible source of exogenous flow shocks. Such forced trading is known to generate large liquidity and price effects, but its real impacts have not been studied extensively. We find that both country- and firm-level investment growth rates are significantly affected by these exogenous capital shocks, and that their effect is more pronounced for firms whose marginal investment decisions are more equity-reliant.
\end{abstract}

* Jotikasthira and Lundblad are at University of North Carolina, Chapel Hill and Ramadorai is at Saïd Business School, Oxford-Man Institute of Quantitative Finance, and CEPR. Correspondence to: tarun.ramadorai@sbs.ox.ac.uk. 


\title{
How do foreign investors impact domestic economic activity? Evidence from India and China.
}

\begin{abstract}
There has been renewed advocacy for restrictions on international financial flows in the wake of the recent financial crisis. Motivated by this trend, we explore the extent to which cross-border flows affect real economic activity. Unlike previous research efforts that focus on aggregated capital flows, we exploit novel data on forced trading by global mutual funds as a plausible source of exogenous flow shocks. Such forced trading is known to generate large liquidity and price effects, but its real impacts have not been studied extensively. We find that both country- and firm-level investment growth rates are significantly affected by these exogenous capital shocks, and that their effect is more pronounced for firms whose marginal investment decisions are more equity-reliant.
\end{abstract}




\section{Introduction}

Despite a large body of research, there remains a heated debate in the international finance literature on the costs and benefits of financial globalization. ${ }^{1}$ An often-heard critique of financial openness is that it increases the macro-economic vulnerability of countries and the probability of a financial crisis (see Stiglitz $(2000,2010)$, for example). This critique arises from the perception that foreign capital not only increases financial market volatility, but also generates undesired volatility in the real economy. Indeed, the perceived disadvantages of unbridled capital flows, often termed "hot money" in popular parlance, have brought back proposals for a Tobin tax on cross-border capital flows (see Eichengreen, Tobin, and Wyplosz (1995)), and has led to the IMF publicly abandoning its position that capital controls are inappropriate for most countries (see Ostry et al. (2010)).

The literature on the effects of financial openness on macro-volatility finds generally mixed results (see, for example, Kose, Prasad and Terrones (2003), Bekaert, Harvey and Lundblad (2006), Froot and Ramadorai (2008), Fratzscher and Imbs (2009)). However, a limitation of these approaches is that one cannot easily identify shocks to foreign capital. The estimated macro effects of foreign capital flows have generally been linked either to de jure measures of financial market restrictions that may or may not be binding, or to composite measures of realized, aggregated capital flows that could endogenously be driven by a host of factors, including expectations about future economic activity.

In sharp contrast, we exploit novel international data from Emerging Portfolio Fund Re-

\footnotetext{
${ }^{1}$ On the benefit side, early research focusing on general capital account openness generally finds mixed results for economic growth (see Eichengreen (2001) for a survey); however, recent evidence suggests a robust link between financial openness and economic growth. For example, Bekaert, Harvey and Lundblad (2005) and Quinn and Toyoda (2008) document strong macro-economic growth effects associated with financial openness. This evidence is further supported by micro-level studies (see Gupta and Yuan (2009) at the industry-level and Mitton (2006) at the firm-level). See Kose, Prasad, Rogoff, and Wei (2009) and Prasad, Rogoff, Wei, and Kose (2003) for a counter argument.
} 
search (EPFR) on global mutual fund flows and security holdings to explore the real implications of forced trading. The global mutual funds we consider are largely domiciled in developed countries, but invest in the emerging world. We focus on the part of their flows to emerging economies that is driven by shocks to fund assets under management occasioned by withdrawals and investments by their developed country-domiciled retail investor base. Using this cleaner identification of capital flow shocks, we investigate their impact on subsequent real economic activity in emerging markets, in an attempt to illuminate the mixed evidence in the existing literature.

Our use of this identification strategy is motivated by a recent stream of the asset pricing literature that explores the effects of financial asset "fire sales." This literature demonstrates that forced trading can generate significant deviations of asset prices from fundamental values. ${ }^{2}$ Indeed, building on Coval and Stafford (2007), Jotikasthira, Lundblad, and Ramadorai (2012) show that subscriptions and redemptions in global mutual funds result in forced trading by these funds in emerging markets. Furthermore, they find that this forced trading generates significant price impact and subsequent reversals in equity markets in the emerging world.

Using this observation as our starting point, we check whether this plausibly exogenous component of global capital flows has implications for emerging market economic activity. We do so first using broad macroeconomic aggregates, and subsequently measure economic activity using data on firms located in two large and important emerging markets, namely China and India. We focus on these two large markets for three main reasons. First, these countries are the targets of a significant amount of global mutual fund investment, which means that

\footnotetext{
${ }^{2}$ Shleifer and Vishny (1992) present a theoretical model in which the forced selling of industry-specific assets by financially distressed owners may cause transaction prices to significantly dip below assets' fundamental values. While this theory was first formulated for real asset sales, more recently, many authors have shown that these ideas are extremely useful for understanding asset market liquidity, and the valuation of financial assets.
} 
the primary identification strategy that we employ is more likely to yield clear outcomes in either direction in this setting. Second, both China and India are especially cognizant of the potential vulnerabilities they have to global capital flows, and there have been important policy debates in both markets on this important issue. Finally, the two countries house an interesting cross-section of firms that vary in their needs for external finance, enabling our use of this additional source of variation to better identify the specific mechanism through which the effects of capital flow shocks operate. In addition, our use of firm-level data is motivated by literature suggesting that firm-level investment and capital expenditure data represents a cleaner measure of economic activity in economies such as China and India, where aggregate statistics may be noisy indicators of true underlying economic activity (see Shah, 2008, for example).

In our empirical implementation, we find that capital shocks from forced reallocations by global mutual funds are statistically and economically significant predictors of investment and GDP growth at the country level. This suggests that capital flow shocks do affect real economic outcomes. To better identify the channels through which these effects operate, in our firmlevel analysis, we hypothesize that capital shocks are likely to have the greatest impact on firms that demonstrate greater degrees of equity reliance. We employ two different versions of an equity reliance measure borrowed from Baker, Stein and Wurgler (2003) (following Kaplan and Zingales (1997)) to classify firms. Using these classifications, we find evidence that Chinese and Indian firms that are more equity reliant demonstrate a greater degree of investment sensitivity to capital supply shocks.

Our new approach represents a contribution to the literatures in the fields of corporate finance and international finance. For international finance, our use of a cleaner identification strategy to measure the impacts of foreign capital flows on domestic economic activity is novel. 
Using this identification strategy, we uncover an important channel through which capital flows driven by constraints on financial intermediaries transmit economic crises to otherwise unrelated markets in which they invest. In the area of corporate finance, despite the documented empirical evidence that asset fire-sales induce price distortions, little is known about the extent to which these occurrences materially affect firms' decision-making. ${ }^{3}$ Our evidence that these events have a measurable impact on firm investment provides confirmation that the connection between asset market liquidity and firms' decisions may indeed be as important as previously thought, especially in the aftermath of an important liquidity crisis.

The organization of the paper is as follows. Section 2 describes the data employed in the study. Section 3 provides detail at the country level where we focus on the link between variation in capital flows experienced by global funds and the broad macro-performance of the real economy in which those funds are invested. Section 4 presents evidence at the firm level for China and India, where we connect the forced reallocations of global funds with individual firm performance; we focus on the implication of forced reallocations as they relate to firm-level cross-sectional variation in the reliance on external finance. Section 5 provide a robustness check of our firm-level findings, and Section 6 concludes.

\section{Data}

To conduct our exploration, we employ four main sources of data: global mutual fund data from Emerging Portfolio Fund Research (EPFR), country equity index return and market cap-

\footnotetext{
${ }^{3}$ It should be noted that there is a growing literature in corporate finance that explores the implications of the supply effects of equity and credit market capital for firms' investment, issuance, payout policy, and capital structure decisions [see Baker (2009) for a recent survey]. Further, several articles document a link between the liquidity of the secondary market and security issuance and/or firm capital structure decisions. The analysis of fire sales in this context will help to shed further light on this issue, using a clean identification of liquidity events using funding shocks to mutual funds that are plausibly exogenous to firms' decisions.
} 
italization data from Standard and Poor's Emerging Markets Database (EMDB), Gross Fixed Capital Formation (GFCF) and Gross Domestic Product (GDP) from the respective national accounts through Datastream, and firm-level accounting data from Compustat North America and Global. In this section, we will discuss the construction and summary statistics of country-level variables. We will discuss firm-level variables in more detail in Section 4 .

The sample period for our EPFR data is from March 1996 to June 2009 (with the exception of January 2000, for which data is missing for all funds). We obtain the country-level equity index returns, GFCF, and GDP growth data for the same period. While we do conduct some analyses across a collection of twenty-five emerging economies, the majority of our analyses focus on China and India given their importance detailed above. For these two countries, Table 1 provides descriptive statistics for country-level variables. The frequency is monthly, except for Gross Fixed Capital Formation (GFCF), which is quarterly (year-on-year). ${ }^{4}$

Before proceeding to market or macro data, we first highlight the significant role that the funds covered by EPFR play in these two domestic equity markets. We have an average of 186 and 155 funds that are active in China and India, respectively, representing 1.1 to 3.5 percent of total market capitalization. However, Dahlquist et al. (2003) show that only a fraction of the shares issued in emerging markets are freely traded. Therefore, we scale these ownership percentages using the float-adjustment factors reported in Table 1 of Dahlquist et al. and find that the average holdings of EPFR funds are $3.63 \%$ and $5.83 \%$ of float-adjusted market capitalization in China and India, respectively. The corresponding quarterly standard deviations are $2.05 \%$ and $1.15 \%$, which suggest that fund holdings vary significantly over time and this variation may be useful for us in identifying the impact of funds' trading. Figure 1 provides a

\footnotetext{
${ }^{4}$ These series are in U.S. dollars, as the effects we later report are unrelated to exchange rates, consistent with the evidence presented in Jotikasthira, Lundblad, and Ramadorai (2012).
} 
time-series plot of the aggregate holding of EPFR funds as a percentage of beginning-of-month total net assets $(T N A)$ for both countries. It is notable that the EPFR funds' holding is, in all periods, smaller in China than in India. We find similar holding patterns for other emerging markets (see Jotikasthira, Lundblad, and Ramadorai (2012), Table I for additional detail), i.e., both China and India are representative of the full sample of countries. Jotikasthira, Lundblad, and Ramadorai (2012) show that reallocation of these funds (particularly flow-induced forced reallocations) can constitute a large fraction of market volume, hence these funds do play a significant role in determining the liquidity environment in these markets.

In addition to holdings, both stock returns and GFCF also vary significantly over time. The average monthly stock return and its associated standard deviation is $1.64 \%$ and $8.48 \%$ (for China) and $1.38 \%$ and $9.18 \%$ (for India). GFCF also varies over time, the standard deviations equal $7.66 \%$ (for China) and $14.58 \%$ (for India).

To measure flow-induced fund reallocation, we construct a measure of emerging market capital that is exposed to forced trading following Jotikasthira, Lundblad, and Ramadorai (2012). Their measure is called Flow-Implied Fund Allocation Changes, or FIFA, and it captures the amount of capital that a particular emerging market could expect to see enter or exit as a result of the subscriptions or redemptions faced by invested funds. We define this as the product of the dollars allocated by each fund to each emerging market with the percentage subscription/redemption requests experienced by the fund, and aggregate the measure across all funds in each period. For each country-month, FIFA is measured as

$$
F I F A_{c, t}=\sum_{i=1}^{N_{F}} \text { flow }_{i, t}^{*} \cdot \text { allocation }_{i, c, t-1} \cdot T N A_{i, t-1},
$$

divided by country c's market capitalization (MCAP), where flow $w_{i, t}^{*}=$ flow $_{i, t}+$ flow $_{i, t-1}+$ 
flow $_{i, t-2}$ is the sum of capital flows experienced by fund $i$ over the quarter prior to and including month $t, \omega_{i, c, t-1}$ is the percent of fund $i$ 's $T N A$ invested in country $c$ at the end of month $t-1$.

To provide a concrete example of the construction of FIFA, assume that a fund's portfolio allocation to India measured at the end of December 2007 is $25 \%$, and the fund's TNA reported at the end of December 2007 is USD 100 million. If the fund's total flow over the NovemberDecember-January quarter is $10 \%$, this yields USD 2.5 million as the fund-country dollar FIFA at the end of January 2008 (i.e., if flows were proportionally allocated, this is how much the fund would additionally invest in India). The next step is to sum the measure across all funds investing in India at the end of January 2008, and normalize it by Indian market capitalization reported in end-December 2007. Put simply, FIFA captures the amount of capital that a particular emerging market could see enter or exit as a result of the flows faced by invested funds.

For China and India, Table 2 provides additional detail on the fund-level data from EPFR. There are 663 and 583 unique funds that invest at some point in China and India, respectively. These funds range from pure country funds, investing only in one country, to regional funds holding concentrated positions in one geographical area, to global funds than invest all around the world in many countries. There is significant cross-fund variation in investor flows into and out of funds (and fund-level returns), which suggests that flow-induced fund reallocations may be significant in certain time-periods. We employ these data to construct FIFA. Returning to Table 1, we show that there is a significant degree of variability in FIFA across countries and time; this suggests that there might be periods in which countries are particularly susceptible to global capital flows associated with forced trading. 


\section{Country-Level Analysis}

We begin our analysis at the country-level, using a broad cross-section of twenty-five emerging markets. Once we demonstrate that real economy effects are present in periods when FIFA is elevated, we go on to explore firm-level investment effects by exploiting cross-sectional data from China and India.

To begin our country-level analysis, Figures 2 and 3 present, for each country, the relationship between FIFA and equity market returns (Figure 2) and aggregate investment (Figure 3). FIFA is significantly related to price determination; Figure 2 plots the time series of (a 6-month moving average of) FIFA and stock index returns for China (Panel A) and India (Panel B). The correlations between the two series are 0.41 and 0.31 , respectively, highlighting the fact that forced trading by global mutual funds does generate significant price effects in local financial markets in this restricted sample, as previously documented in the asset fire-sales literature (see Coval and Stafford (2007) and Jotikasthira, Lundblad, and Ramadorai (2012)). We now turn to the extent to which flow-induced reallocations affect the real economy.

Figure 3 provides preliminary evidence that FIFA is related to domestic economic activity as measured by aggregate investment in each country. Specifically, Figure 3 plots the time series of the 6-month moving average of FIFA and GFCF for China (Panel A) and India (Panel B). The correlations between the two series are 0.24 and 0.30 , respectively, suggesting that domestic firms are affected by the capital supply shock associated with mutual funds' forced trading.

To more formally explore the relationship between FIFA and real economic activity, we estimate panel regressions of GFCF and GDP growth, separately, on FIFA, and Table 3 reports the results. We use a broad set of countries, as opposed to just China and India, in order 
to improve the empirical power of our country-level analysis. The observations are countryquarters across twenty-five emerging countries, ${ }^{5}$ and the dependent variables, GFCF and GDP growth rates, are annual and measured over the period from the contemporaneous quarter $t$ to quarter $t+3$. The control variables, $\operatorname{GFCF}(t-3, t)$ and $\operatorname{GDP}(t-3, t)$ are lagged GFCF and GDP growth rates, included to control for potential serial correlation. All regressions include country fixed effects, and report Newey-West standard errors using four lags.

Panel A reports coefficient estimates that demonstrate that FIFA is associated with future GDP and aggregate investment growth. Specifications (1) and (3) explore the effects of FIFA on investment and GDP growth, respectively, in the absence of lagged growth rates and controls. Specifications (2) and (4) provide similar analyses with the inclusion of these additional controls. While the $R^{2}$ 's from these regressions are not large, we should note that reported growth rates across emerging countries are rather noisy, and that forecasting economic growth rates is well-known to be a difficult enterprise. Nonetheless, in each case, the coefficient on FIFA is statistically significant, indicating that flow-induced reallocations are linked to broad economic effects.

To better understand the magnitude of these effects, Panel B reports the impact of a one standard deviation movement in FIFA for China and India using the estimates in columns (2) and (4) (with the additional lags as control variables). Such a shock to FIFA would engender a $1.00 \%(0.49 \%)$ reaction in GFCF (GDP) for China and a 1.29\% (0.64\%) move in GFCF (GDP) for India. Despite the fact that economic growth rates are relatively more volatile in the emerging world (and the baseline average growth rates larger as well), these effects are by

\footnotetext{
${ }^{5}$ These regressions include the twenty-five emerging markets examined in Jotiaksthira, Lundblad, and Ramadorai (2012). Aside from China and India, they include Argentina, Brazil, Chile, Colombia, Czech Republic, Hong Kong, Hungary, Indonesia, Israel, Jordan, Malaysia, Mexico, Morocco, Pakistan, Philippines, Poland, Russia, South Africa, South Korea, Taiwan, Thailand, Turkey, and Venezuela.
} 
no means small.

While these results are suggestive of the fact that FIFA affects economic growth rates across our various specifications, these results do not help to uncover the channels through which these effects operate. The most plausible hypothesis is that equity price distortions driven by flowinduced reallocations alter corporate decision-making, perhaps through changes in the ability of firms to raise equity finance. To better understand whether there is evidence to support this channel, we rely on cross-sectional variation in Chinese and Indian firms' reliance on equity capital. If firms that are more reliant on equity capital also exhibit the largest investment effects in the face of capital flow shocks, this would provide insights into the mechanism through which capital flows impact the real economy.

\section{Firm-Level Analysis}

We employ data on a large number of listed firms in China and India from Compustat Global. Following Chen, Goldstein, and Jiang (2007), we construct two measures of firm investments, namely the change in total assets scaled by beginning-of-period assets, i.e., percentage growth in assets, and firm capital expenditure scaled by beginning-of-period assets. ${ }^{6}$ In China, we have semi-annual balance-sheet information up to the end of 2002 and quarterly data thereafter, but many firms do not report semi-annually or quarterly. For India, balance-sheet information is reported only annually. ${ }^{7}$ As a result of these data limitations, we use the annual frequency, as opposed to the quarterly frequency employed in the country-level analysis. That said, offsetting the lower frequency in the firm-level analysis, we have a large number of cross-sectional

\footnotetext{
${ }^{6}$ Since R\&D is missing for most firms in this database, we do not use capital expenditure plus R\&D - another measure of investment in Chen et al. (2007).

${ }^{7}$ In both countries, most firms do report income statements on a quarterly basis.
} 
observations in each year.

Our sample period for China is fiscal years 2003 to 2009, which end in December each year. The start period is dictated by the fact that Figures 2 and 3 show that there is virtually no identifiable variation in FIFA prior to 2003, and the end period reflects the end of the EPFR sample data in June 2009. For India, the sample period includes fiscal years (ending March of the following year) 2001 to 2009 since the number of Indian firms in Compustat Global is relatively small prior to 2001. Before proceeding, it should be noted that the quality of accounting data across China and India is often thought to be quite limited (Bhattacharya, Daouk, and Welker (2003), among many others, discuss the relatively poor state of corporate accounting in emerging markets). Given the degree of measurement error, the econometric hurdle for statistical significance is quite high. As a result, capturing firm-level investment effects, as they relate to FIFA, represents a clear a priori challenge.

To begin, we plot the aggregated time series of firms' investments, measured by annual percentage growth in assets, along with GFCF and FIFA in Figure 4, which provides preliminary evidence that firm-level investments are positively related to GFCF and FIFA in each country.. In each fiscal year, we aggregate asset growth across firms by averaging the measure both on an equally weighted and on a beginning-of-year asset weighted basis. In the graph, we plot FIFA in the last quarter of the prior year, as this most likely corresponds to the time period in which firms typically plan their investment and secure funding for the year. The correlations between equally-weighted asset growth and FIFA are 0.46 (for China) and 0.18 (for India). The correlations between equally-weighted asset growth and GFCF for the two countries are 0.64 and 0.33 , respectively. Together, the time-series evidence suggests that, on average, domestic firms' aggregated investments are affected by capital supply shocks associated with mutual funds' forced trading in a fashion similar to what we observe for GFCF obtained at the macro 
level.

To better understand the channels through which this effect operates, we now exploit crosssectional variation within each country. In particular, we hypothesize that mutual funds' forced trading affects firms by altering stock prices and therefore impacting costs of equity capital. In the fire sales literature, these price effects (and their subsequent reversals) are often viewed as departures from fundamental value. The broader question here is whether such price distortions disproportionately affect firms that are more equity reliant. Specifically, firms that rely more on equity capital to finance their marginal investments should, under this hypothesis, be more affected by capital supply shocks (as measured by FIFA).

To measure a firm's reliance on equity capital, we use Baker, Stein, and Wurgler (2003)'s modified version of the Kaplan and Zingales (1997) index, henceforth $K Z$ index. Kaplan and Zingales (1997) conduct a detailed study of low-dividend manufacturing firms with positive real sales growth to test Fazzari, Hubbard, and Petersen (1988)'s conclusion that investment-cash flow sensitivities reflect financial constraints. Kaplan and Zingales classify firms into discrete categories of financial constraints and then run an ordered logit to relate their classifications to accounting variables. The index underlying these categories of financial constraints is a simple linear function of accounting variables. The choice of accounting variables employed various somewhat in the literature, for example, Lamont, Polk, and Saa-Requejo (2001) include five variables, including Tobin's $Q$. However, Baker et al. (2003) remove Tobin's $Q$ from the formula, arguing that $Q$ has ambiguous signals for a firm's capital constraint, reflecting both investment opportunities (demand for capital) and mispricing (cost of/access to capital). 
Therefore, following Baker et al. (2003), for firm $i$ in year $t$, we calculate $K Z$ as: ${ }^{8}$

$$
K Z_{i t}=-1.002 \frac{C F_{i t}}{\text { Asset }_{i t-1}}-39.368 \frac{D_{\text {Iset }}}{\text { Ast }-1}-1.315 \frac{\text { Cash }_{i t}}{\text { Asset }_{i t-1}}+3.139 L E V_{i t}
$$

where $C F$ denotes cash flows from operations, calculated as earnings before interests and taxes plus depreciation and amortization, $D I V$ denotes cash dividends, Cash denotes cash balances and $L E V$ denotes book leverage.

In our empirical implementation, we use purely U.S. data to compute these numbers for the years of our sample period, and measure the component of external equity dependence as an industry characteristic. To be more specific, we employ annual data from 1990 to 2006 (avoiding the recent crisis period) to calculate the index for each U.S. firm-year and then calculate $K Z$ as the median of all firm-years in each SIC 2-digit sector. Having done so, we then assign a U.S.-data-based $K Z$ score to each firm in China and India based on its SIC 2-digit sector.

Our use of U.S. data, is motivated by the desire to identify an industry's natural equity reliance in the absence of many of the financial frictions that are both present and often impactful in the emerging world. The methodology clearly demands sufficient similarity across countries with regards to the firms that share an SIC 2-digit (we explore robustness to this assumption below), but it has the significant advantage of creating a equity reliance measure that is exogenous to the investment decisions of Chinese and Indian firms (because of both geographic proximity and because it is constructed from data over the pre-crisis period). Moreover, this helps us to avoid potential endogeneity as domestic firms' investment and other balance sheet characteristics are jointly determined. Of course, to ensure that this use of U.S. data does not

\footnotetext{
${ }^{8}$ Kaplan and Zingales (1997) use a variety of qualitative and quantitative information to subjectively classify their 49 sample firms into several categories (ranging from 'not financial constrained' to 'financial constrained'). For this reason, we cannot recreate their formula.
} 
drive our results, we check robustness to this assumption in the next section.

To better understand how the index classifies industries, note that the mean and standard deviation of the $K Z$ index are 1.05 and 2.93, respectively. Miscellaneous manufacturing (SIC2 $=39)$ and transportation by air $(\mathrm{SIC} 2=45)$ are among the most equity dependent sectors, whereas miscellaneous retail $(\mathrm{SIC} 2=59)$ and leather and leather footwear $(\mathrm{SIC} 2=31)$ are among the least equity dependent sectors.

Having constructed the measure, to test whether firms that are more equity dependent make investment decisions that are more sensitive to capital supply shocks (as measured by FIFA), we run the following panel regression, separately for each country:

$$
I N V_{i, j, t}=\text { constant }+\beta \times F I F A_{t-1}+\gamma \times\left(F I F A_{t-1} \times K Z_{j}\right)+\text { control } \operatorname{variables}_{i, j, t-1}+\varepsilon_{i, j, t}
$$

where $I N V_{i, j, t}$ is investment of firm $i$ in SIC 2-digit sector $j$ during year $t$. It is important to note that we do not observe flow-induced fund re-allocations at the firm level $(i)$. Our mutual fund data provides portfolio allocations only at the country level, so we can only measure an average investment effect associated with country-level capital supply shocks. This level of aggregation presumably biases against finding firm-level effects. As in a typical investment regression, we also include the following firm-level control variables: log of total assets, book leverage, Tobin's $Q$, and ratio of cash flows from operations over assets, all measured at the beginning of year except the cash flows from operations. We exclude utility firms (SIC 1-digit $=4$ ). Our sample includes about 5,500 non-missing firm-years from China (from the lowest of 275 firms in 2003 to the highest of 1,256 firms in 2009) and about 3,500 non-missing firm-years from India (from the lowest of 87 firms in 2001 to the highest of 731 firms in 2008). Tong and Wei (2011) run a similar regression to explore how the composition of capital flows affects the 
degree of credit crunch faced by firms in emerging countries during the 2007-09 crisis. $^{9}$

Table 4 presents results for the firm-level investment growth panel regressions for China (columns (1)-(4)) and India (columns (5)-(8)). The regressions are separated by the measure of firm-level investment growth; columns (1)-(2) and (5)-(6) present the results for specifications that include the percentage growth in total assets (Asset Growth) on the left-hand side, whereas columns (3)-(4) and (7)-(8) present the results for specifications that include capital expenditure as a percentage of previous year-end assets (CAPX/Assets) on the left-hand side. As with the country-level analyses presented above, these panel regressions are predictive in nature in that the right-hand side variables are lagged one year for each firm. We include a lagged dependent variable in each case to control for potential serial correlation, and standard errors, presented in parentheses, are clustered by industry.

First, columns (1) [for China] and (5) [for India] show that future firm level asset growth is linked to country-level FIFA (however, this is only statistically significant for China). More importantly, this effect is more pronounced, on average, for firms from industries that are more equity-dependent as measured by the U.S.-constructed $K Z$ index. The interaction effect between FIFA and the $K Z$ index is statistically significant for firms from both countries (at the $1 \%$ level for China and the $10 \%$ level for India). These effects are economically significant. For example, a one-standard deviation increase in FIFA increases asset growth by $2.21 \%$ for Chinese firms in an industry with $K Z$ index at the 10 th percentile and $2.93 \%$ for those in an industry with $K Z$ index at the 90th percentile. The same numbers for Indian firms are $-0.02 \%$ and $1.11 \%$, respectively.

While these economic effects are significant, they may not best describe the total impact

\footnotetext{
${ }^{9}$ Tong and Wei (2011) use Rajan and Zingales (1998)'s index as a measure of dependence on external finance for investment and cash conversion cycle as a measure of dependence on external finance for working capital. Both measures are calculated as the SIC 2-digit median of U.S. firms.
} 
since FIFA is serially correlated and its movement can be quite large over a longer period. To illustrate this point, Figure 5 plots changes in (equally-weighted) average asset growth for firms in different quartiles of $K Z$ index during two-year periods of large increases and decreases in FIFA for China (Panel A) and India (Panel B). From 2005 to 2007, when FIFA increased substantially for China, the average asset growth increased by $20.42 \%$ (10.31\%) for Chinese firms in the top (bottom) quartile of $K Z$ index. For India from 2003 to 2005, FIFA increased and the average asset growth increased by $25.39 \%$ (20.40\%) for Indian firms in the top (bottom) quartile of $K Z$ index. The figure also shows that the reverse is true during two-year periods in which FIFA decreased for each country.

The differential effects of FIFA on investment documented above are robust to using a different measure of investment. Table 4 Columns (3) [for China] and (7) [for India] show similar evidence that firm-level capital expenditure is also linked to country-level FIFA. In this case, the effect is statistically significant for both countries similar to what we see in our country-level analyses. Furthermore, as with the asset growth regressions, the interaction term between FIFA and the $K Z$ index demonstrates that this effect is also stronger for firms that come from industries that are more equity-dependent. Taken together, this evidence strongly suggests that exogenous capital shocks, as measured by flow-induced fund reallocations driven by developed market investor mutual fund flows, do significantly affect firm-level investment decisions, particularly for Chinese and Indian firms that are, on average, more equity dependent. Fire sales do appear to have some measurable real-economy effects.

We also consider an alternative version of this regression framework for which we replace the interaction term between FIFA and the $K Z$ index with an interaction term between FIFA and a $0 / 1$ indicator that takes the value of 1 when the firm is in the top quartile of equity dependence and 0 otherwise. This isolates the subset of firms in each country that are likely 
the most affected by capital shocks if the hypothesis is valid. As the link between investment growth and FIFA may not vary linearly in the $K Z$ index, this version permits an alternative that avoids such an assumption. Columns (2), (4), (6) and (8) replicate the previous regressions with this simple variant. In each case, the results are quite similar; in particular, the link between firm-level investment growth and FIFA is significantly stronger for firms that are in the top quartile of equity-dependence. For example, in response to a one-standard deviation increase in FIFA, Chinese firms in the top $K Z$-index quartile increase their investment by $1.67 \%$ more than other Chinese firms.

Finally, across all the regressions presented, we observe that the effects associated with several of the control variables are statistically significant. While this is not the case for all of the control variables, the effects associated with Tobin's $Q$, operating cash-flows, and the lagged dependent variable are statistically significant and of the expected signs. As these variables are generally important in investment regressions presented throughout the literature, this gives comfort that we are measuring relevant quantities despite the challenges associated with using emerging market accounting data. Further, the R-squareds in these predictive regressions are reasonably large considering the noisy nature of our dependent variables, suggesting we are capturing an important component of the variation in firm-level investment activity within these two countries.

\section{Robustness Check: KZ Using Local Firms}

One potential criticism of our approach is that U.S. and Chinese/Indian firms from the same SIC 2-digit sector may not be particularly comparable, as they could reflect very different points in the firm maturation process or the labor/capital choice. Perhaps more significantly, 
it is quite plausible that the institutional environment in China or India affects the degree of equity reliance for a firm, regardless of the benchmark that might be established from U.S. data. For example, a Chinese or Indian firm that is particularly well connected may not suffer the consequences of a capital supply shock despite general industry-wide characteristics (see La Porta, Lopez-de-Silanes, Shleifer, and Vishny (1997, 1998), among many others, for a discussion of the links between a country's institutional environment and the functioning of its financial markets).

We consider an alternative construction of the $K Z$ index. Specifically, we explore the robustness of our cross-sectional results by using an alternative $K Z$ index calculated using purely domestic accounting data for each country. As before, $K Z$ is still the median of all firm-years in the SIC 2-digit in each country during the period prior to and including 2006, but it is constructed from the relevant data items based on the Chinese or Indian firms in the sample. The measure, as before, uses pre-crisis data so as to avoid the contaminating effects of the crisis. In this alternative specification, our sample is slightly larger since some domestic industries are not present in the U.S., thereby dropping out of our main analysis presented above.

Table 5 presents results for the firm-level investment growth panel regressions for China (columns (1)-(4)) and India (columns (5)-(8)) where we replace the U.S.-based $K Z$ index used in Table 4 with the pre-crisis domestic data-based $K Z$ index. As before, the regressions are separated by the two measure of firm-level investment growth (asset growth and capital expenditure); columns (1)-(2) and (5)-(6) present the results for specifications that include the percentage growth in total assets (Asset Growth) on the left-hand side, whereas columns (3)-(4) and (7)-(8) present the results for specifications that include capital expenditure as a percentage of previous year-end assets ( $C A P X /$ Assets) on the left-hand side. Standard errors, 
presented in parentheses, are clustered by industry.

The panel regression results for these alternative specifications are broadly similar to those presented in Table 4 with the U.S.-based $K Z$ index. We find that Chinese and Indian firms' investment growth rates, however measured, are generally linked to FIFA and that the effect is stronger for firms that are more equity-dependent. In six of the eight specifications, the interaction effect between FIFA and equity-dependence is statistically significant. This is true despite the fact that the local accounting data employed to construct the local $K Z$ index is much noisier than the U.S. data used in the estimates presented in Table 4; this is again just a reflection of the fact that accounting quality is quite limited in these markets, potentially raising the hurdle for detecting the hypothesized effects. As before, the effects associated with the control variables are broadly similar to that presented above and the predictive regression R-squareds remain large. Taken together, Tables 4 and 5 show that firm-level investment growth is significantly affected by FIFA and that the effect appears to be more pronounced for firms whose marginal investment decisions are more equity-reliant.

\section{Conclusion}

Using novel international data on mutual fund flows and security holdings, we explore the real implications of mutual fund forced trading. Borrowing from the financial asset fire sales literature, we identify a component of cross-border capital flows that may be very impactful for domestic economic activity. Specifically, a focus on the subset of global mutual fund activity that is driven largely by foreign retail investors may provide cleaner identification of capital supply shocks that affect subsequent real activity in a distant country.

Our results provide compelling evidence that both country- and firm-level investment growth 
rates are significantly affected by plausibly exogenous capital shocks; furthermore, the effect appears to be more pronounced for firms whose marginal investment decisions are more equityreliant. Taken together, the evidence in this paper suggests that financial asset fire sales' impact extends beyond financial market liquidity and price determination, also affecting real economic decisions. For the international economics and finance literatures, this finding implies that important components of cross-border financial flows may significantly impact economic activity, i.e., all flows are not created equal.

As our evidence is somewhat nuanced in its focus on flows conditional on certain conditions, the lessons we can draw for the appropriateness or efficacy of categorical Tobin taxes are less clear. A number of papers document the economic benefits of financial market and capital account openness. Our work suggests that further research on these potential trade-offs is warranted. 


\section{References}

[1] Baker, M., 2009, Capital market driven corporate finance, Annual Review of Financial Economics 1, 181-205.

[2] Baker, M., J. C. Stein, and J. Wurgler, 2003, When does the market matter? Stock prices and the investment of equity-dependent firms, Quarterly Journal of Economics 118, 969-1005.

[3] Bekaert, G., C. R. Harvey, and C. Lundblad, 2005, Does financial liberalization spur growth?, Journal of Financial Economics 77, 3-56.

[4] Bekaert, G., C. R. Harvey, and C. Lundblad, 2006, Growth volatility and financial liberalization, Journal of International Money and Finance 25, 370-403.

[5] Bhattacharya, U., H. Daouk, and M. Welker, 2003, The world price of earnings opacity, Accounting Review 78, 641-678.

[6] Chen, Q., I. Goldstein, and W. Jiang, 2007, Price informativeness and investment sensitivity to stock price, Review of Financial Studies 20, 619-650.

[7] Coval, J., and E. Stafford, 2007, Asset fire sales (and purchases) in equity markets, Journal of Financial Economics 86, 479-512.

[8] Dahlquist, M., L. Pinkowitz, R. Stulz, and R. Williamson, 2003, Corporate governance and the home bias, Journal of Financial and Quantitative Analysis 38, 87-110.

[9] Eichengreen, B., 2001, Capital account liberalization: What do cross-country studies tell us?, World Bank Economic Review 15, 341-365.

[10] Eichengreen, B., J. Tobin, and C. Wyplosz, 1995, Two cases for sand in the wheels of international finance, Economic Journal, 105, 162-172.

[11] Fazzari, S. M., R. G. Hubbard, and B. C. Petersen, 1988, Financing constraints and corporate investment, Brookings Papers on Economic Activity, 141-206.

[12] Fratzscher, M., and J. Imbs, 2009, Risk sharing, finance, and institutions in international portfolios, Journal of Financial Economics 94, 428-447.

[13] Froot, K. A., and T. Ramadorai, 2008, Institutional portfolio flows and international investments, Review of Financial Studies 21, 937-971.

[14] Gupta, N., and K. Yuan, 2009, On the growth effect of stock market liberalizations, Review of Financial Studies 22, 4715-4752.

[15] Jotikasthira, C., C. Lundblad, and T. Ramadorai, 2012, Asset fires sales and purchases and the international transmission of funding shocks, Journal of Finance (forthcoming).

[16] Kaplan, S. N., and L. Zingales, 1997, Do investment-cash flow sensitivities provide useful measures of financing constraints?, Quarterly Journal of Economics 112, 169-215.

[17] Kose, M. A., E. Prasad, K. Rogoff, and S. J. Wei, 2009, Financial liberalization: A reappraisal, IMF Staff Papers 56, 8-62.

[18] Kose, M. A., E. Prasad, and M. E. Terrones, 2003, How does globalization affect the synchronization of business cycles?, American Economic Review 93, 57-62. 
[19] La Porta, R., F. Lopez-de-Silanes, A. Shleifer, and R. W. Vishny, 1997, Legal determinants of external finance, Journal of Finance 52, 1131-1150.

[20] La Porta, R., F. Lopez-de-Silanes, A. Shleifer, and R. W. Vishny, 1998, Law and finance, Journal of Political Economy 106, 1113-1155.

[21] Lamont, O., C. Polk, and J. Saa-Requejo, Financial constraints and stock returns, Review of Financial Studies 14, 529-554.

[22] Mitton, T., 2006, Stock market liberalization and operating performance at the firm level, Journal of Financial Economics 81, 625-647.

[23] Ostry, Jonathan D., Atish R. Ghosh, Karl Habermeier, Marcos Chamon, Mahvash S. Qureshi, and Dennis B.S. Reinhardt, 2010, "Capital Inflows: The Role of Controls," IMF Staff Position Note.

[24] Prasad, E., K. Rogoff, S. J. Wei, and M. A. Kose, 2003, Effects of financial globalization on developing countries: Some empirical evidence, Economic and Political Weekly, 4319-4330.

[25] Quinn, D. P., and A. M. Toyoda, 2008, Does capital account liberalization lead to growth?, Review of Financial Studies 21, 1403-1449.

[26] Rajan, RG., and L. Zingales, 1998, Financial dependence and growth, American Economic Review 88, 559-586.

[27] Shah, A., 2008, New issues in macroeconomic policy, Business Standard India, 26-54.

[28] Shleifer, A., and R. W. Vishny, 1992, Liquidation values and debt capacity: A market equilibrium approach, Journal of Finance 47, 1343-1366.

[29] Stiglitz, J. E., 2000, Capital market liberalization, economic growth, and instability, World Development 28, 1075-1086.

[30] Stiglitz, J. E., 2010, Risk and global economic architecture: Why full financial integration may be undesirable, American Economic Review 100, 388-392.

[31] Tong, H., and S. J. Wei, 2011, The composition matters: Capital inflows and liquidity crunch during a global economic crisis, Review of Financial Studies 24, 2023-2052. 


\section{Table 1: Country-Level Summary Statistics}

This table presents descriptive (time-series) statistics of country-level variables for China and India. The sample period is from March 1996 to June 2009. The frequency is monthly, except for the Gross Fixed Capital Formation (GFCF) which is quarterly (year-on-year). For each country-month, Flow-Implied Fund Allocation Changes, or FIFA, is measured as

$$
F I F A_{c, t}=\sum_{i=1}^{N_{F}} \text { flow }_{i, t}^{*} \cdot \text { allocation }_{i, c, t-1} \cdot T N A_{i, t-1}
$$

divided by country c's market capitalization (MCAP), where flow $_{i, t}^{*}=$ flow $_{i, t}+$ flow $_{i, t-1}+$ flow $_{i, t-2}$, is the sum of capital flows experienced by fund $i$ over the quarter prior to and including month $t$, and allocation $_{i, c, t-1}$ is the percent of fund $i$ 's TNA invested in country $c$ at the end of month $t-1$. The flow, allocation, and TNA data are from EPFR. Market capitalizations are the latest year-end numbers. Number of funds is the number of funds in each month that have non-zero allocation in the country. Holding is the total dollar holding of these funds in the country. Index return is the return on the IFC Global Index for the country (measured in USD) up to October 2008 and the return on the S\&P Broad Market Index thereafter.

\begin{tabular}{llccccc}
\hline \multirow{2}{*}{ Country } & Variable & Mean & $\begin{array}{c}\text { Standard } \\
\text { Deviation }\end{array}$ & 1st PCT & Median & 99th PCT \\
\hline \multirow{2}{*}{ China } & FIFA (X 100) & 0.01 & 0.03 & -0.07 & 0.00 & 0.12 \\
& Number of funds & 186 & 103 & 42 & 171 & 355 \\
& Holding/MCAP (\%) & 1.13 & 0.64 & 0.29 & 1.07 & 2.67 \\
& Index return (\%) & 1.64 & 8.48 & -16.15 & 1.84 & 24.63 \\
& GFCF (\%) & 17.18 & 7.66 & 6.85 & 15.56 & 36.86 \\
& & & & & & \\
India & FIFA (X 100) & 0.01 & 0.05 & -0.10 & 0.00 & 0.15 \\
& Number of funds & 155 & 71 & 45 & 134 & 281 \\
& Holding/MCAP (\%) & 3.48 & 0.69 & 2.26 & 3.44 & 5.50 \\
& Index return (\%) & 1.38 & 9.18 & -19.18 & 1.80 & 18.26 \\
& GFCF (\%) & 13.35 & 14.58 & -14.54 & 11.67 & 44.90 \\
\hline \hline
\end{tabular}




\section{Table 2: Fund-Level Summary Statistics}

This table provides descriptive (pooled) statistics regarding the funds in the EPFR sample. Only funds that invest in China or India at any point during the sample period are included. The sample period is from March 1996 to June 2009. The frequency is monthly. The statistics are pooled across fund-months. The number of unique funds is the total number of unique funds that invest in the country at any point in time during the sample period. The number of fund-months is the total number of observations over which the statistics are calculated. Total net assets (TNA) are the total asset value in U.S. dollar at the end of each month. Number of countries invested is the total number of countries, including both developed and emerging countries, in which the fund has non-zero allocation. Allocation to each country and cash holding are measured as a percentage of TNA. Month-to-month change in cash holding, fund flows, and fund returns are measured as a percentage of the beginning-of-month TNA.

\begin{tabular}{|c|c|c|c|c|c|c|}
\hline Country & Variable & Mean & $\begin{array}{c}\text { Standard } \\
\text { Deviation }\end{array}$ & 1st PCT & Median & 99th PCT \\
\hline \multirow[t]{9}{*}{ China } & Number of unique funds & 663 & & & & \\
\hline & Number of fund-months & 29,747 & & & & \\
\hline & TNA (\$ Million) & 823 & 2,517 & 4 & 186 & 13,529 \\
\hline & Number of countries held & 13 & 8 & 2 & 10 & 34 \\
\hline & Allocation per country (\%) & 13.72 & 14.62 & 2.62 & 9.31 & 54.38 \\
\hline & Cash holding (\%) & 3.23 & 4.81 & -8.00 & 2.45 & 19.65 \\
\hline & Change in cash holding (\%) & 0.02 & 3.62 & -9.71 & 0.00 & 10.00 \\
\hline & Flow (\%) & 0.13 & 7.43 & -21.40 & -0.15 & 30.62 \\
\hline & Return (\%) & 0.97 & 7.64 & -20.86 & 1.51 & 18.40 \\
\hline \multirow[t]{9}{*}{ India } & Number of unique funds & 583 & & & & \\
\hline & Number of fund-months & 24,530 & & & & \\
\hline & TNA (\$ Million) & 902 & 2,579 & 4 & 211 & 14,752 \\
\hline & Number of countries held & 14 & 8 & 1 & 12 & 34 \\
\hline & Allocation per country (\%) & 17.47 & 27.74 & 2.54 & 7.68 & 100.90 \\
\hline & Cash holding (\%) & 3.14 & 5.22 & -10.10 & 2.49 & 19.68 \\
\hline & Change in cash holding (\%) & 0.01 & 4.10 & -10.63 & 0.00 & 10.87 \\
\hline & Flow (\%) & 0.08 & 7.27 & -20.86 & -0.12 & 29.00 \\
\hline & Return (\%) & 1.02 & 7.82 & -20.44 & 1.50 & 19.30 \\
\hline
\end{tabular}




\section{Table 3: Country-Level Predictive Growth Regression}

This table reports results from panel regressions of GFCF and GDP growths on FIFA, over the sample period from February 1996 to October 2008. The observations are country-quarters, where all 25 emerging countries examined in Jotiaksthira, Lundblad, and Ramadorai (2011) are included. The dependent variables, GFCF and GDP growths, are annual and measured over the period from the contemporaneous quarter $t$ to quarter $t+3$. FIFA is measured as described in Table 1 . The control variables, $\operatorname{GFCF}(t-3, t)$ and $\operatorname{GDP}(t-3, t)$ are lagged GFCF and GDP growths, included to control for the current information set and potential serial correlations. All regressions include country dummies. Newey-West standard errors using four lags are in parentheses. Panel A reports the coefficient estimates, and Panel B reports the estimated effects of a one standard deviation movement in FIFA for China and India using the estimates in columns (2) and (4). ***, and *** refer to statistical significance at $10 \%, 5 \%$, and $1 \%$ levels, respectively.

Panel A: Regression Coefficients

\begin{tabular}{|c|c|c|c|c|}
\hline & $\begin{array}{c}(1) \\
\operatorname{GFCF}(t, t+3) \\
\end{array}$ & $\begin{array}{c}(2) \\
\operatorname{GFCF}(t, t+3) \\
\end{array}$ & $\begin{array}{c}(3) \\
\operatorname{GDP}(t, t+3) \\
\end{array}$ & $\begin{array}{c}(4) \\
\operatorname{GDP}(t, t+3)\end{array}$ \\
\hline$F I F A(t)$ & $\begin{array}{c}11.406^{* *} \\
(4.619)\end{array}$ & $\begin{array}{c}9.954 * * \\
(4.179)\end{array}$ & $\begin{array}{l}5.759 * * \\
(2.926)\end{array}$ & $\begin{array}{l}4.908^{*} \\
(2.841)\end{array}$ \\
\hline $\operatorname{GFCF}(t-3, t)$ & & $\begin{array}{c}0.411^{* * *} \\
(0.082)\end{array}$ & & $\begin{array}{l}0.113^{*} \\
(0.060)\end{array}$ \\
\hline $\operatorname{GDP}(t-3, t)$ & & $\begin{array}{l}-0.074 \\
(0.128)\end{array}$ & & $\begin{array}{c}0.094 \\
(0.090)\end{array}$ \\
\hline Country dummies & YES & YES & YES & YES \\
\hline Observations & 1,187 & 1,187 & 1,187 & 1,187 \\
\hline R-squared & 0.072 & 0.068 & 0.186 & 0.113 \\
\hline Panel 1 & timated Econ & mic Effects for & China and In & \\
\hline & Standard Dev & iation of FIFA & $\begin{array}{l}\text { Impact on } \\
\text { GFCF (\%) }\end{array}$ & $\begin{array}{l}\text { Impact on } \\
\text { GDP (\%) }\end{array}$ \\
\hline China & \multicolumn{2}{|c|}{0.0010} & 1.00 & 0.49 \\
\hline India & \multicolumn{2}{|c|}{0.0013} & 1.29 & 0.64 \\
\hline
\end{tabular}


Table 4: Firm-Level Predictive Investment Regression for China and India

This table reports results from panel regressions of firm-level investments on FIFA, over the sample period from 2003 to 2009 for China and from 2001 to 2009 for India. The observations are firm-(fiscal) years, and the data are from Compustat Global. The dependent variables are (i) percentage growth in total assets (Asset Growth $(t+1)$ ) and (ii) capital expenditure as a percentage of previous year-end assets $(\mathrm{CAPX}(t+1) /$ Assets $(t))$, where $t$ refers to the current fiscal year. FIFA is calculated as described in Table 1 for the last quarter of year $t$. $K Z$ index, our measure of equity dependence, is the industry median of U.S. firm-level index, calculated using Baker, Stein, and Wurgler (2003)'s formula. Industry is defined as an SIC 2-digit sector and the median is calculated over the period from 1990 to 2006. Dummy(KZ index Q1) is a dummy variable that equals 1 if $K Z$ index is in the top quartile and 0 otherwise. The control variables, ln(Assets), Book leverage, Tobin's $Q$, and Operating cash flows/Assets, are measured at year $t$ for each local firm. Lagged investments are included to control potential serial correlations. Standard errors clustered by industry are in parentheses. *, **, and *** refer to statistical significance at $10 \%, 5 \%$, and $1 \%$ levels, respectively.

\begin{tabular}{|c|c|c|c|c|c|c|c|c|}
\hline & \multicolumn{4}{|c|}{ China } & \multicolumn{4}{|c|}{ India } \\
\hline & \multicolumn{2}{|c|}{ Asset Growth $(t+1)$} & \multicolumn{2}{|c|}{$\operatorname{CAPX}(t+1) / \operatorname{Assets}(t)$} & \multicolumn{2}{|c|}{ Asset Growth $(t+1)$} & \multicolumn{2}{|c|}{$\operatorname{CAPX}(t+1) / \operatorname{Assets}(t)$} \\
\hline & $(1)$ & $(2)$ & $(3)$ & (4) & (5) & $(6)$ & $(7)$ & $(8)$ \\
\hline FIFA & $\begin{array}{c}17.6832 * * * \\
(2.821)\end{array}$ & $\begin{array}{c}16.0433^{* * *} \\
(3.303)\end{array}$ & $\begin{array}{c}2.2095^{* * * *} \\
(0.603)\end{array}$ & $\begin{array}{c}2.4946 * * * \\
(0.709)\end{array}$ & $\begin{array}{c}1.2654 \\
(2.464)\end{array}$ & $\begin{array}{c}2.0046 \\
(2.809)\end{array}$ & $\begin{array}{l}2.4099 * * \\
(0.955)\end{array}$ & $\begin{array}{c}2.5951^{* *} \\
(1.065)\end{array}$ \\
\hline FIFA $x$ KZ index & $\begin{array}{c}2.1578^{* * * *} \\
(0.586)\end{array}$ & & $\begin{array}{c}0.6448 * * * \\
(0.173)\end{array}$ & & $\begin{array}{l}3.7570 * \\
(2.090)\end{array}$ & & $\begin{array}{l}0.8816^{*} \\
(0.525)\end{array}$ & \\
\hline FIFA x Dummy(KZ index Q1) & & $\begin{array}{c}12.8142^{* *} \\
(6.166)\end{array}$ & & $\begin{array}{l}0.8658 * \\
(0.494)\end{array}$ & & $\begin{array}{l}4.1887^{*} \\
(2.493)\end{array}$ & & $\begin{array}{l}3.0762 * * \\
(1.334)\end{array}$ \\
\hline $\ln$ (Assets) & $\begin{array}{l}0.0044 * \\
(0.002)\end{array}$ & $\begin{array}{l}0.0046 * \\
(0.002)\end{array}$ & $\begin{array}{l}0.0027 * * \\
(0.001)\end{array}$ & $\begin{array}{l}0.0029 * * \\
(0.001)\end{array}$ & $\begin{array}{c}-0.0184^{* * * *} \\
(0.006)\end{array}$ & $\begin{array}{c}-0.0184^{* * *} \\
(0.006)\end{array}$ & $\begin{array}{c}-0.0048^{* * * *} \\
(0.002)\end{array}$ & $\begin{array}{c}-0.0048^{* * *} \\
(0.002)\end{array}$ \\
\hline Book leverage & $\begin{array}{l}-0.0247 \\
(0.015)\end{array}$ & $\begin{array}{l}-0.0254^{*} \\
(0.015)\end{array}$ & $\begin{array}{l}-0.0031 \\
(0.006)\end{array}$ & $\begin{array}{l}-0.0034 \\
(0.006)\end{array}$ & $\begin{array}{c}0.0034 \\
(0.024)\end{array}$ & $\begin{array}{r}0.0037 \\
(0.024)\end{array}$ & $\begin{array}{l}0.0182^{* *} \\
(0.008)\end{array}$ & $\begin{array}{l}0.0175^{* *} \\
(0.008)\end{array}$ \\
\hline Tobin's $Q$ & $\begin{array}{l}0.0085^{* *} \\
(0.003)\end{array}$ & $\begin{array}{l}0.0085^{* *} \\
(0.003)\end{array}$ & $\begin{array}{l}0.0026^{* *} \\
(0.001)\end{array}$ & $\begin{array}{l}0.0026^{* *} \\
(0.001)\end{array}$ & $\begin{array}{c}0.0438 * * * \\
(0.007)\end{array}$ & $\begin{array}{c}0.0438^{* * * *} \\
(0.007)\end{array}$ & $\begin{array}{c}0.0078^{* * * *} \\
(0.002)\end{array}$ & $\begin{array}{c}0.0077 * * * \\
(0.002)\end{array}$ \\
\hline Operating CF/ Assets & $\begin{array}{c}0.8694^{* * *} \\
(0.053)\end{array}$ & $\begin{array}{c}0.8878^{* * * *} \\
(0.055)\end{array}$ & $\begin{array}{c}0.1461 * * * \\
(0.012)\end{array}$ & $\begin{array}{c}0.1485 * * * \\
(0.014)\end{array}$ & $\begin{array}{c}0.4272 * * * \\
(0.064)\end{array}$ & $\begin{array}{c}0.4271^{* * * *} \\
(0.065)\end{array}$ & $\begin{array}{c}0.2178 * * * \\
(0.022)\end{array}$ & $\begin{array}{c}0.2172 * * * \\
(0.022)\end{array}$ \\
\hline Lagged dependent variable & $\begin{array}{c}0.0653^{* * *} \\
(0.022)\end{array}$ & $\begin{array}{c}0.0630^{* * *} \\
(0.022)\end{array}$ & $\begin{array}{c}0.4682 * * * \\
(0.019)\end{array}$ & $\begin{array}{c}0.4692 * * * \\
(0.019)\end{array}$ & $\begin{array}{c}0.2227 * * * \\
(0.021)\end{array}$ & $\begin{array}{c}0.2229 * * * \\
(0.021)\end{array}$ & $\begin{array}{c}0.4255^{* * * *} \\
(0.018)\end{array}$ & $\begin{array}{c}0.4256^{* * *} \\
(0.018)\end{array}$ \\
\hline Constant & $\begin{array}{c}0.0014 \\
(0.021)\end{array}$ & $\begin{array}{l}-0.0007 \\
(0.022)\end{array}$ & $\begin{array}{l}-0.0024 \\
(0.010)\end{array}$ & $\begin{array}{l}-0.0037 \\
(0.010)\end{array}$ & $\begin{array}{c}0.1701^{* * *} \\
(0.040)\end{array}$ & $\begin{array}{c}0.1697 * * * \\
(0.040)\end{array}$ & $\begin{array}{c}0.0423^{* * *} \\
(0.008)\end{array}$ & $\begin{array}{c}0.0426 * * * \\
(0.008)\end{array}$ \\
\hline Observations & 5,574 & 5,574 & 5,453 & 5,453 & 3,515 & 3,515 & 3,295 & 3,295 \\
\hline R-squared & 0.133 & 0.133 & 0.361 & 0.360 & 0.147 & 0.147 & 0.307 & 0.308 \\
\hline
\end{tabular}


Table 5: Firm-Level Predictive Growth Regression for China and India - Robustness Check

This table reports results from panel regressions of firm-level investments on FIFA, over the sample period from 2003 to 2009 for China and from 2001 to 2009 for India. The observations are firm-(fiscal) years, and the data are from Compustat Global. The dependent variables are (i) percentage growth in total assets (Asset Growth $(t+1)$ ) and (ii) capital expenditure as a percentage of previous year-end assets $(\mathrm{CAPX}(t+1) /$ Assets $(t))$, where $t$ refers to the current fiscal year. FIFA is calculated as described in Table 1 for the last quarter of year $t$. KZ index, our measure of equity dependence, is the industry-country median of local firm-level index, calculated using Baker, Stein, and Wurgler (2003)'s formula. Industry is defined as an SIC 2-digit sector. Dummy(KZ index Q1) is a dummy variable that equals 1 if $K Z$ index is in the top quartile and 0 otherwise. The control variables, $\ln$ (Assets), Book leverage, Tobin's $Q$, and Operating cash flows/Assets, are measured at year $t$ for each local firm. Lagged investments are included to control potential serial correlations. Standard errors clustered by industry are in parentheses. *, **, and $* * *$ refer to statistical significance at $10 \%, 5 \%$, and $1 \%$ levels, respectively.

\begin{tabular}{|c|c|c|c|c|c|c|c|c|}
\hline & \multicolumn{4}{|c|}{ China } & \multicolumn{4}{|c|}{ India } \\
\hline & \multicolumn{2}{|c|}{ Asset Growth $(t+1)$} & \multicolumn{2}{|c|}{$\operatorname{CAPX}(t+1) / \operatorname{Assets}(t)$} & \multicolumn{2}{|c|}{ Asset Growth $(t+1)$} & \multicolumn{2}{|c|}{$\operatorname{CAPX}(t+1) / \operatorname{Assets}(t)$} \\
\hline & $(1)$ & $(2)$ & $(3)$ & $(4)$ & $(5)$ & $(6)$ & $(7)$ & $(8)$ \\
\hline FIFA & $\begin{array}{c}12.4876 * * \\
(5.395)\end{array}$ & $\begin{array}{c}17.4146 * * * \\
(3.346)\end{array}$ & $\begin{array}{l}-0.5139 \\
(1.343)\end{array}$ & $\begin{array}{c}1.5984 * * \\
(0.788)\end{array}$ & $\begin{array}{r}2.2738 \\
(3.477)\end{array}$ & $\begin{array}{r}3.1125 \\
(2.879)\end{array}$ & $\begin{array}{l}-0.9151 \\
(2.343)\end{array}$ & $\begin{array}{c}1.9831^{* *} \\
(0.864)\end{array}$ \\
\hline FIFA $x K Z$ index & $\begin{array}{l}7.6541 * \\
(4.211)\end{array}$ & & $\begin{array}{c}3.6579 * * \\
(1.427)\end{array}$ & & $\begin{array}{l}1.0936 \\
(3.062)\end{array}$ & & $\begin{array}{c}4.6008^{* *} \\
(2.050)\end{array}$ & \\
\hline FIFA x Dummy(KZ index Q1) & & $\begin{array}{l}5.0261 * \\
(3.009)\end{array}$ & & $\begin{array}{c}3.2748^{* *} \\
(1.309)\end{array}$ & & $\begin{array}{r}0.8259 \\
(3.591)\end{array}$ & & $\begin{array}{c}5.9516^{* * *} \\
(1.764)\end{array}$ \\
\hline $\ln$ (Assets) & $\begin{array}{l}0.0042 * \\
(0.002)\end{array}$ & $\begin{array}{l}0.0041 * \\
(0.002)\end{array}$ & $\begin{array}{c}0.0024^{* *} \\
(0.001)\end{array}$ & $\begin{array}{c}0.0023^{* *} \\
(0.001)\end{array}$ & $\begin{array}{c}-0.0180^{* * *} \\
(0.006)\end{array}$ & $\begin{array}{c}-0.0181^{* * *} \\
(0.006)\end{array}$ & $\begin{array}{c}-0.0045^{* * *} \\
(0.002)\end{array}$ & $\begin{array}{c}-0.0047 * * * \\
(0.002)\end{array}$ \\
\hline Book leverage & $\begin{array}{c}-0.0374^{* * *} \\
(0.013)\end{array}$ & $\begin{array}{c}-0.0340^{* *} \\
(0.013)\end{array}$ & $\begin{array}{l}-0.0078 \\
(0.006)\end{array}$ & $\begin{array}{l}-0.0068 \\
(0.005)\end{array}$ & $\begin{array}{l}-0.0027 \\
(0.023)\end{array}$ & $\begin{array}{l}-0.0022 \\
(0.023)\end{array}$ & $\begin{array}{l}0.0141 \\
(0.009)\end{array}$ & $\begin{array}{l}0.0157^{*} \\
(0.008)\end{array}$ \\
\hline Tobin's $Q$ & $\begin{array}{c}0.0080^{* *} \\
(0.003)\end{array}$ & $\begin{array}{c}0.0080^{* *} \\
(0.003)\end{array}$ & $\begin{array}{c}0.0026^{* *} \\
(0.001)\end{array}$ & $\begin{array}{c}0.0026^{* *} \\
(0.001)\end{array}$ & $\begin{array}{c}0.0429 * * * \\
(0.007)\end{array}$ & $\begin{array}{c}0.0429 * * * \\
(0.007)\end{array}$ & $\begin{array}{c}0.0077 * * * \\
(0.002)\end{array}$ & $\begin{array}{c}0.0078^{* * *} \\
(0.002)\end{array}$ \\
\hline Operating CF/ Assets & $\begin{array}{c}0.8754^{* * *} \\
(0.054)\end{array}$ & $\begin{array}{c}0.8777 * * * \\
(0.053)\end{array}$ & $\begin{array}{c}0.1483^{* * *} \\
(0.013)\end{array}$ & $\begin{array}{c}0.1502 * * * \\
(0.013)\end{array}$ & $\begin{array}{c}0.4369 * * * \\
(0.063)\end{array}$ & $\begin{array}{c}0.4372 * * * \\
(0.063)\end{array}$ & $\begin{array}{c}0.2219 * * * \\
(0.023)\end{array}$ & $\begin{array}{c}0.2236 * * * \\
(0.023)\end{array}$ \\
\hline Lagged dependent variable & $\begin{array}{c}0.0655^{* * * *} \\
(0.020)\end{array}$ & $\begin{array}{c}0.0652 * * * \\
(0.020)\end{array}$ & $\begin{array}{c}0.4749 * * * \\
(0.017)\end{array}$ & $\begin{array}{c}0.4730 * * * \\
(0.017)\end{array}$ & $\begin{array}{c}0.2262^{* * * *} \\
(0.020)\end{array}$ & $\begin{array}{c}0.2261 * * * \\
(0.020)\end{array}$ & $\begin{array}{c}0.4259 * * * \\
(0.018)\end{array}$ & $\begin{array}{c}0.4254 * * * \\
(0.018)\end{array}$ \\
\hline Constant & $\begin{array}{r}0.0072 \\
(0.023)\end{array}$ & $\begin{array}{r}0.0068 \\
(0.022)\end{array}$ & $\begin{array}{r}0.0025 \\
(0.009)\end{array}$ & $\begin{array}{c}0.0025 \\
(0.009)\end{array}$ & $\begin{array}{c}0.1686^{* * *} \\
(0.039)\end{array}$ & $\begin{array}{c}0.1686^{* * * *} \\
(0.039)\end{array}$ & $\begin{array}{c}0.0416^{* * *} \\
(0.008)\end{array}$ & $\begin{array}{c}0.0424 * * * \\
(0.008)\end{array}$ \\
\hline Observations & 6,097 & 6,097 & 5,970 & 5,970 & 3,656 & 3,656 & 3,429 & 3,429 \\
\hline R-squared & 0.129 & 0.129 & 0.357 & 0.357 & 0.150 & 0.150 & 0.311 & 0.311 \\
\hline
\end{tabular}




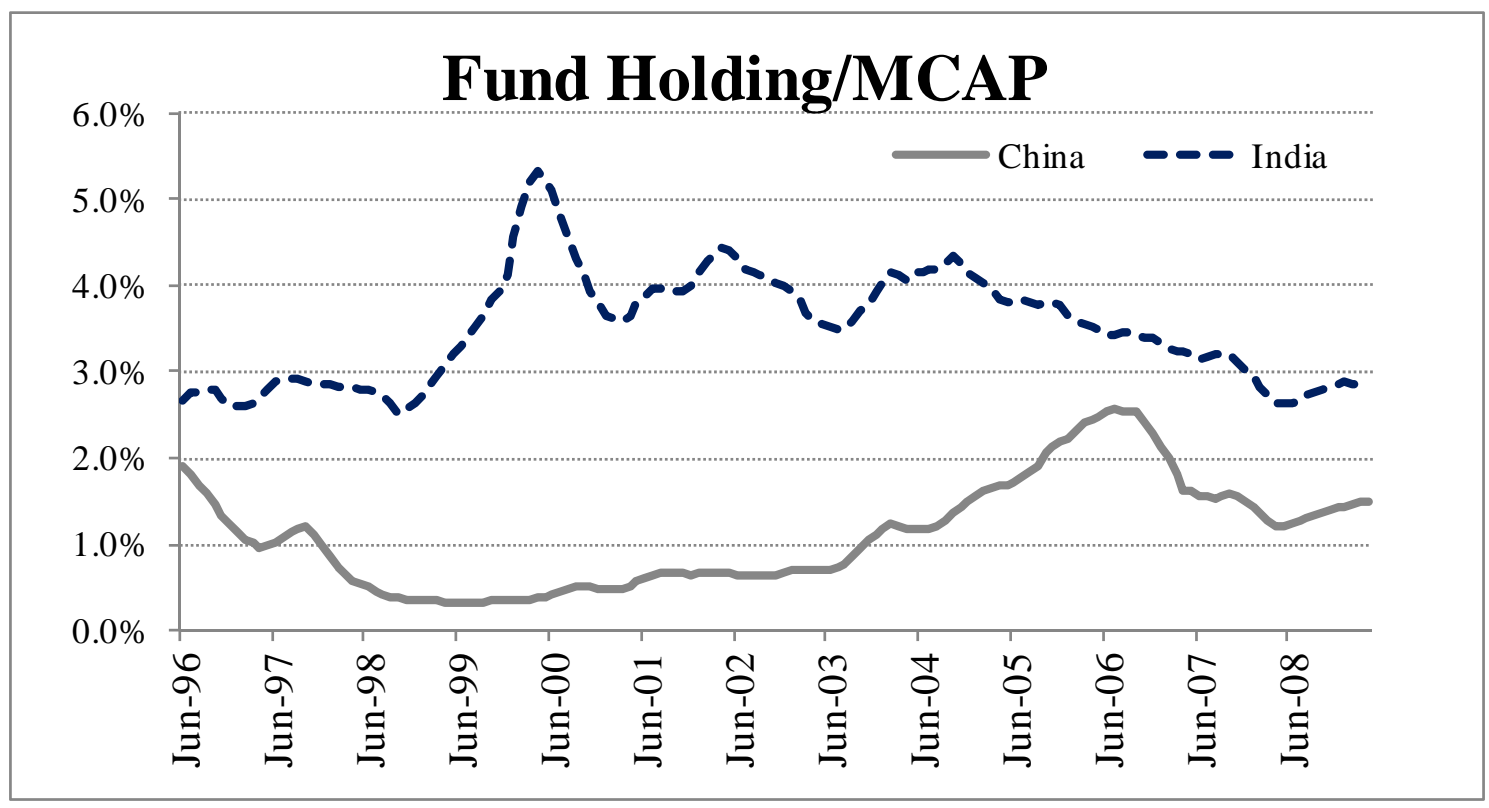

Figure 1: Fund holding over time. This figure plots the aggregate holding of EPFR funds as a percentage of beginning-of-month TNA for China (grey solid line) and India (blue dashed line). The sample period is from March 1996 to June 2009. 


\section{Panel A}

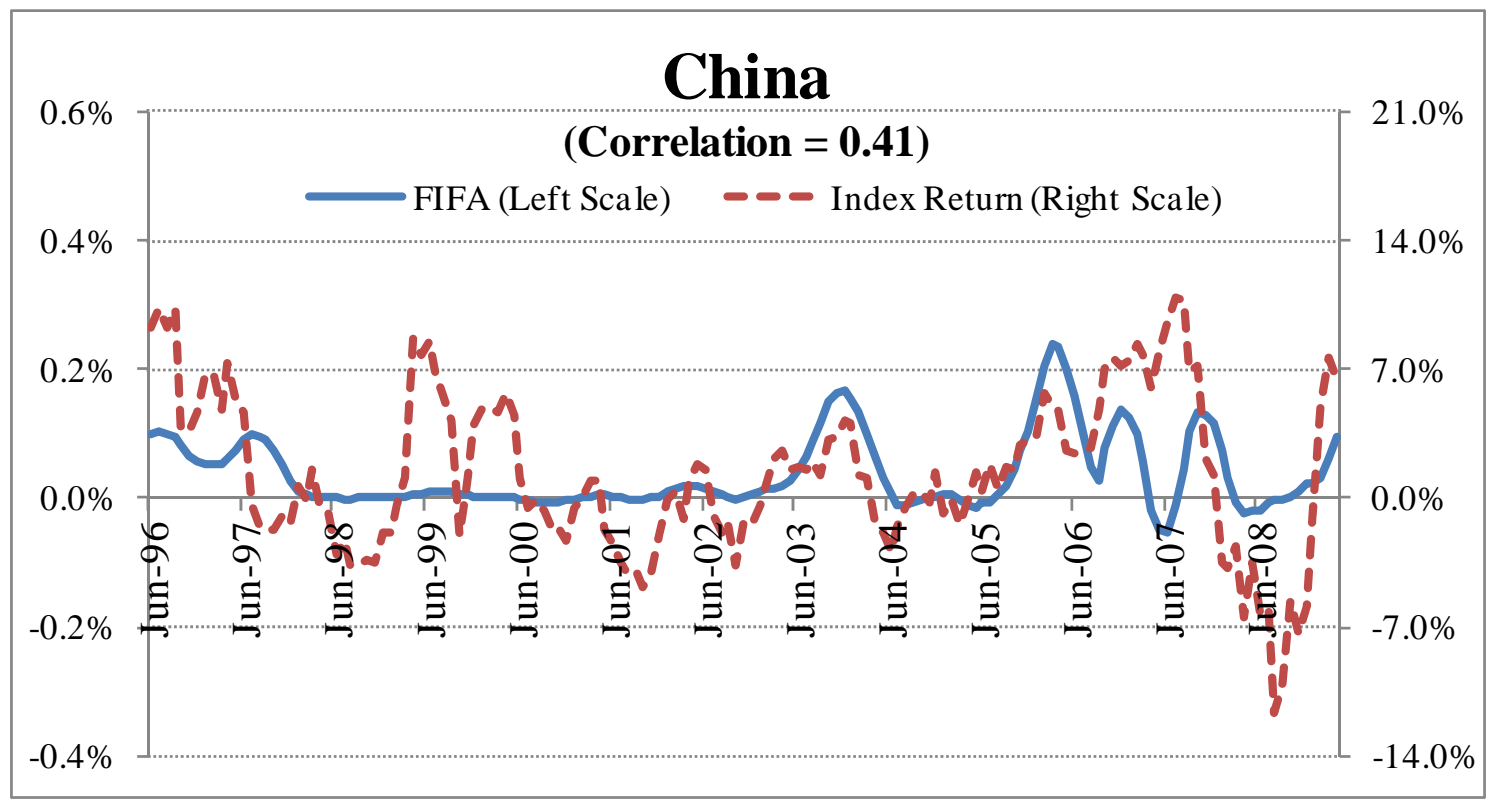

Panel B

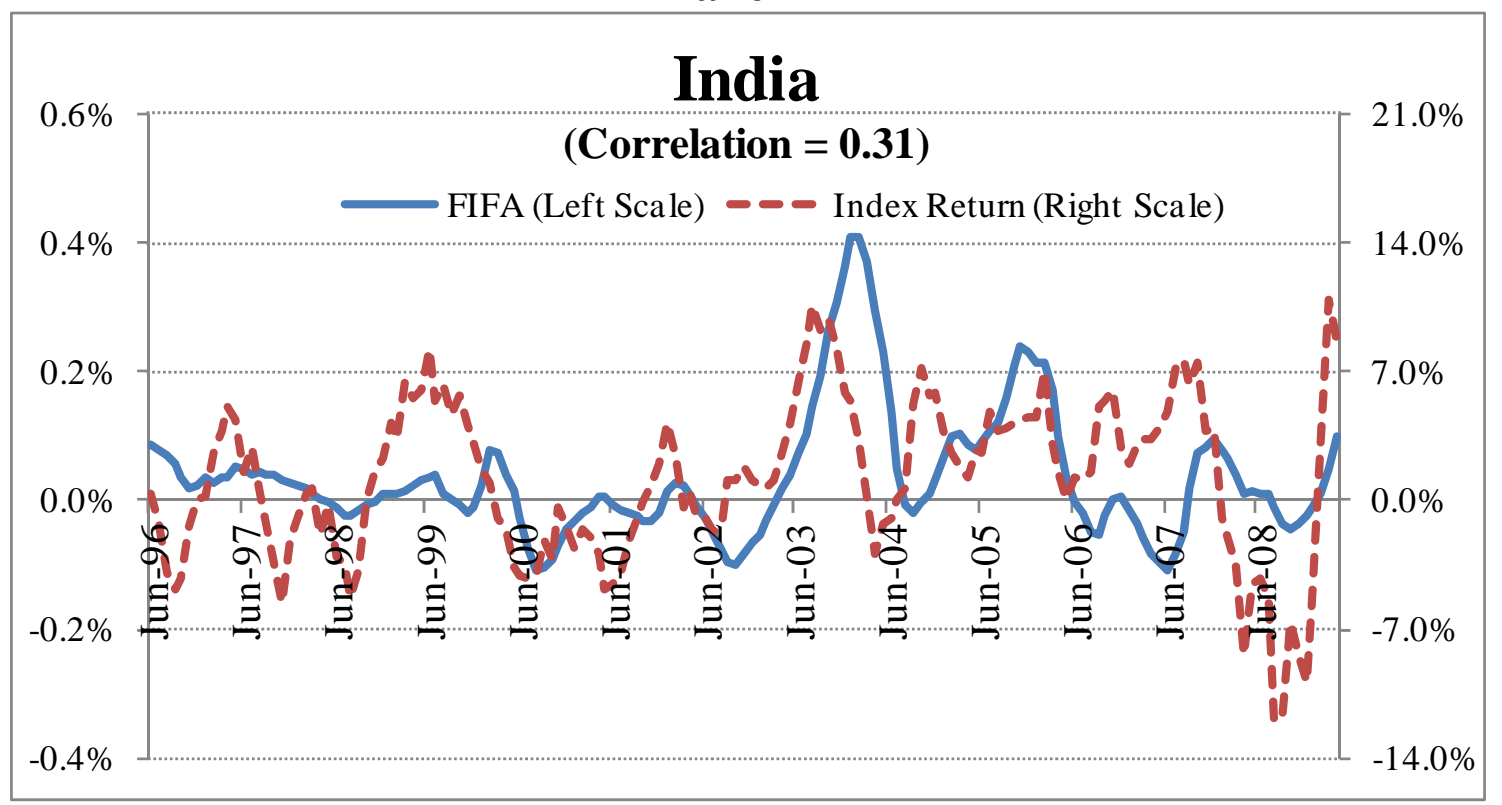

Figure 2: FIFA and stock returns. This figure plots the time series of FIFA (blue solid line) and stock index returns (red dashed line) for China (Panel A) and India (Panel B). The sample period is from March 1996 to June 2009. Both variables are smoothed by taking the 6-month centered moving average. FIFA is measured as described in Table 1. Stock index return (in USD) is the return on the IFC Global Index for the country up to October 2008 and the return on the S\&P Broad Market Index thereafter. 


\section{Panel A}

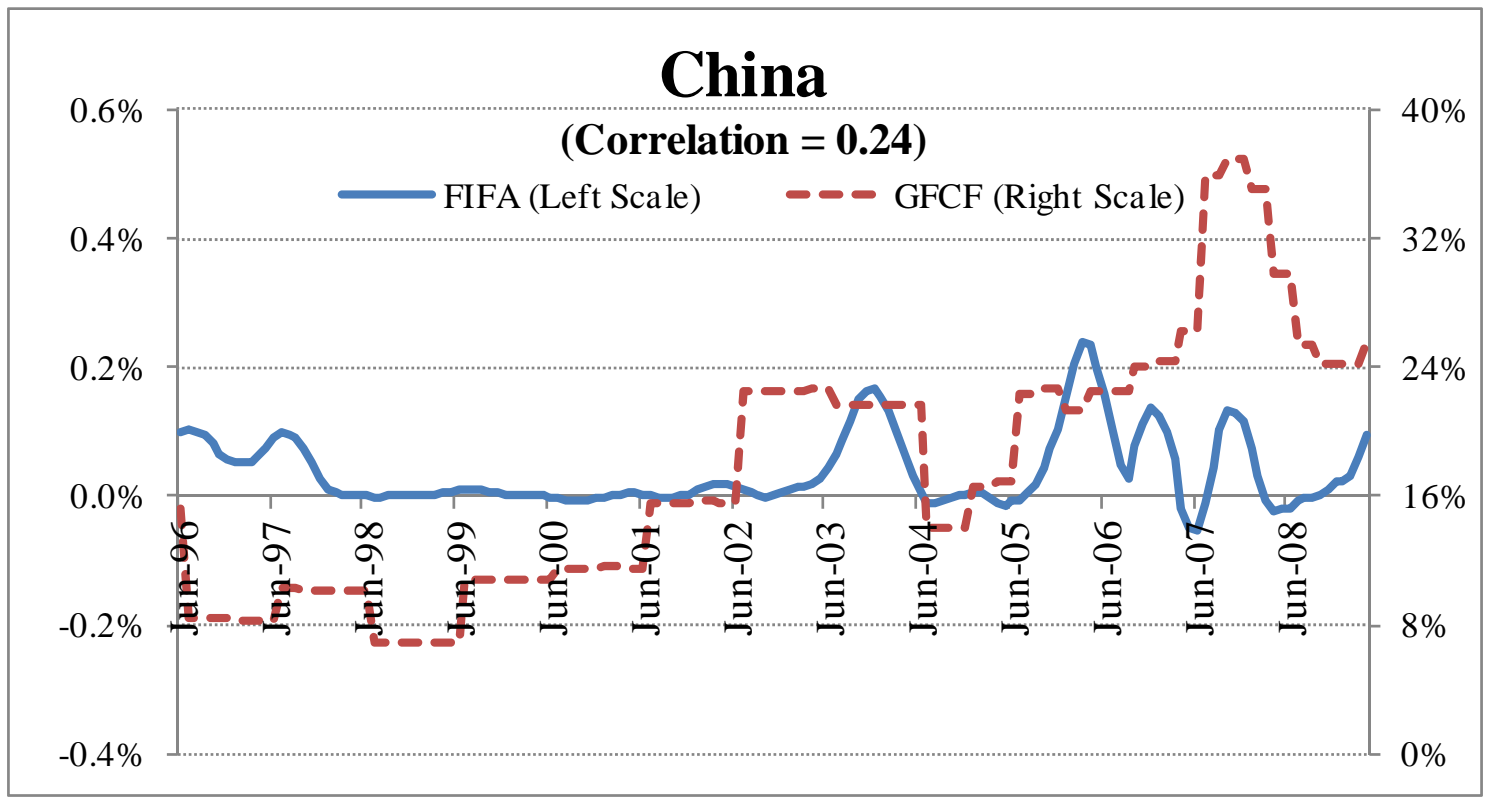

Panel B

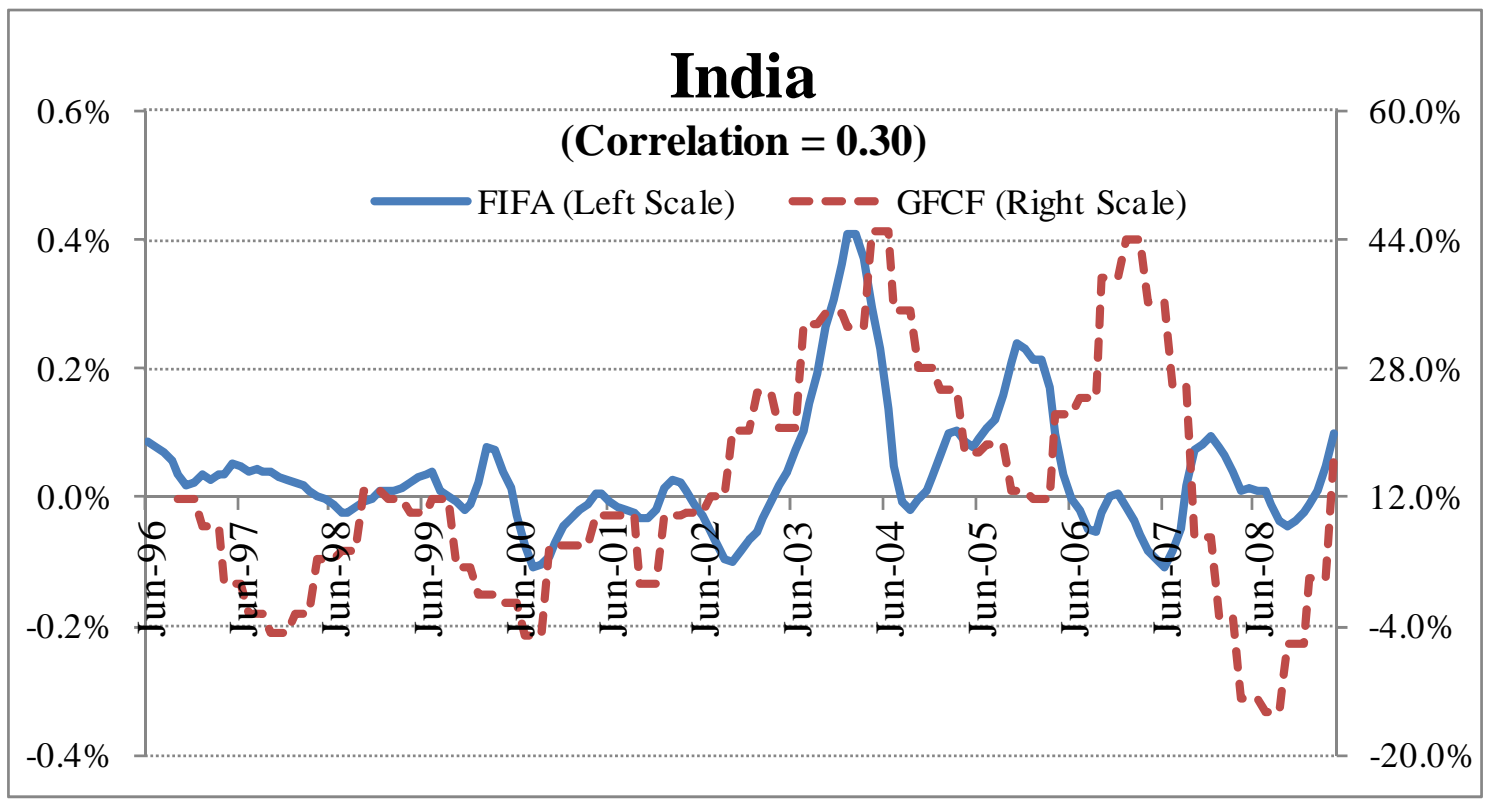

Figure 3: FIFA and GFCF. This figure plots the time series of FIFA (blue solid line) and gross fixed capital formation (GFCF) (red dashed line) for China (Panel A) and India (Panel B). The sample period is from March 1996 to June 2009. Both variables are smoothed by taking the 6-month centered moving average. FIFA is measured as described in Table 1. GFCF is measured as a year-on-year percentage change. 


\section{Panel A}

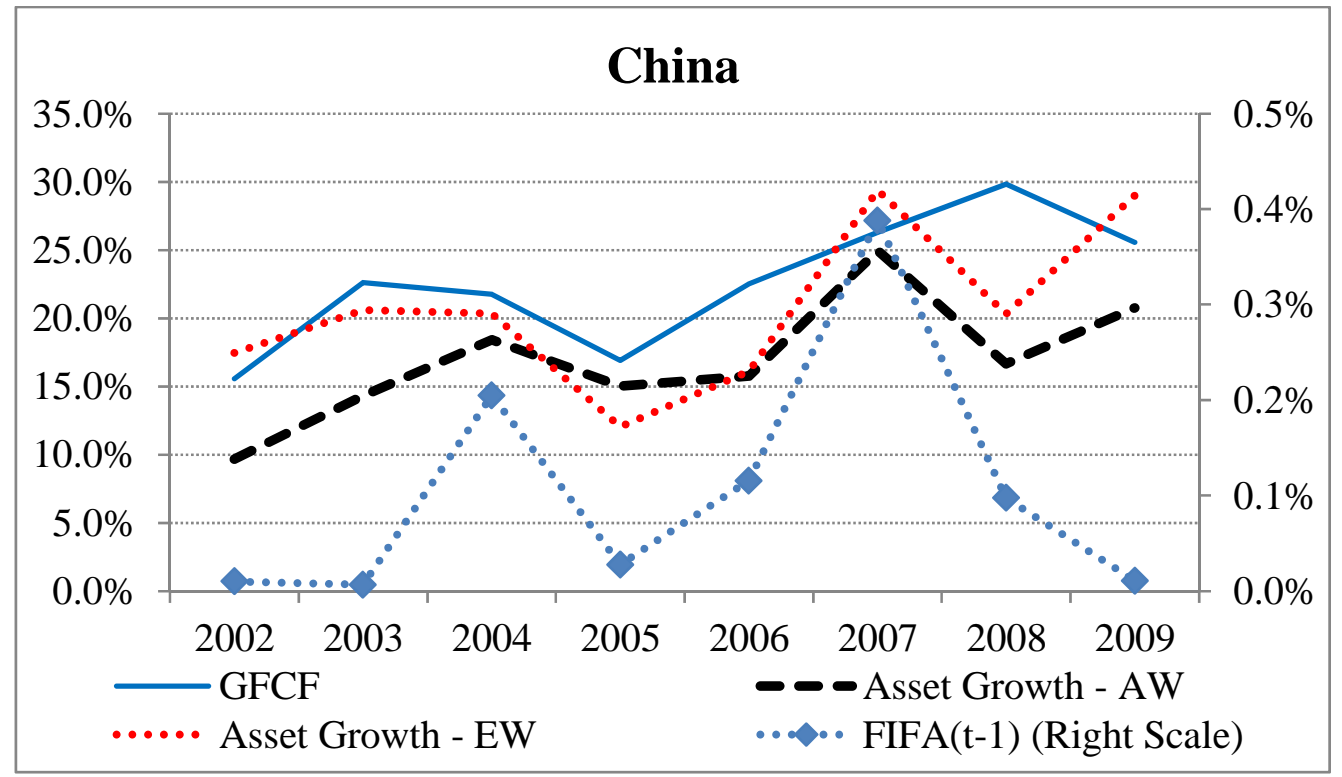

\section{Panel B}

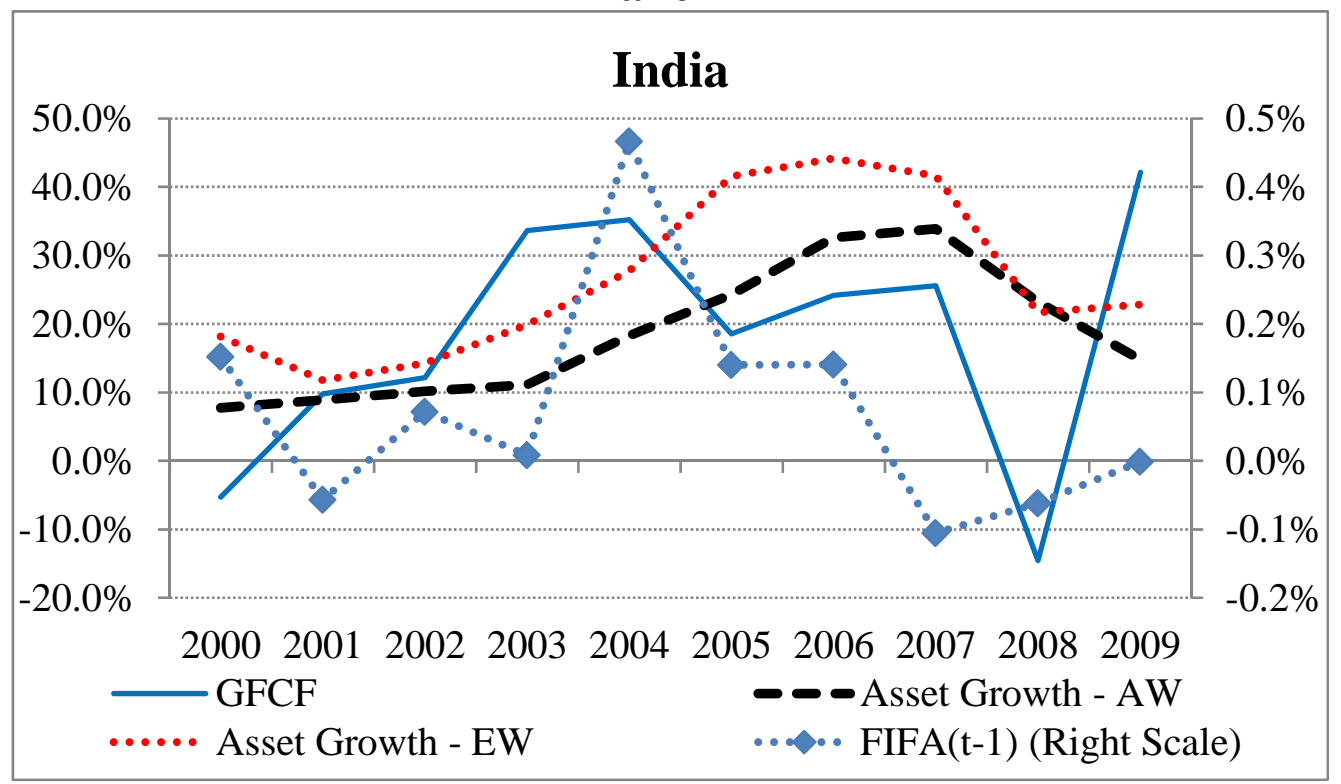

Figure 4: FIFA and Firm-Level Investments. This figure plots the time series of FIFA (blue dotted line with diamond markers), gross fixed capital formation (GFCF) (blue solid line), asset-weighted average asset growth (black dashed line), and equally-weighted asset growth (red dotted line) for China (Panel A) and India (Panel B). The frequency is annual, based on fiscal year which ends in December for China and in March for India. FIFA is measured as described in Table 1, for the last quarter of prior fiscal year. GFCF and asset growth is measured as a year-on-year percentage change. 


\section{Panel A}

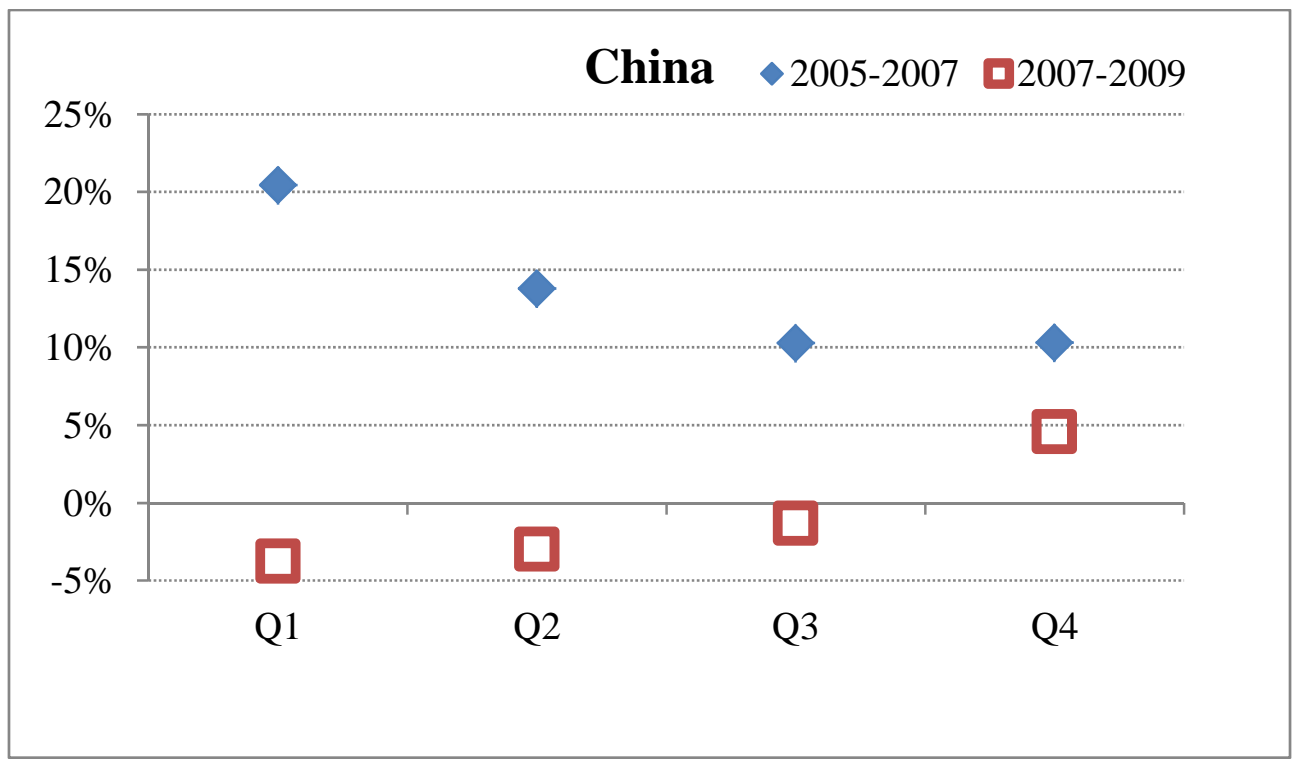

Panel B

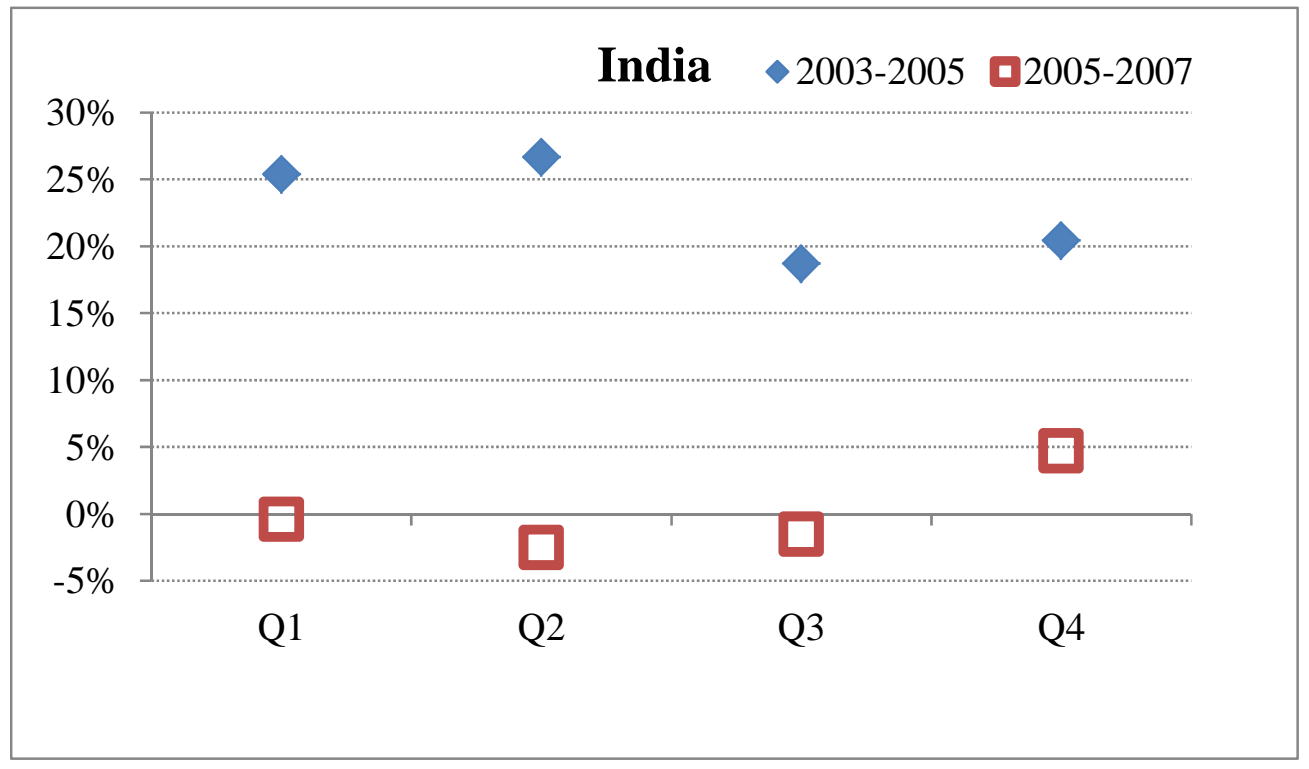

Figure 5: Change in Firm-Level Investments by Quartile of $K \boldsymbol{Z}$ Index. This figure plots changes in (equally-weighted) average investments for firms in different quartiles of $K Z$ index during periods of increase and decrease in FIFA, for China (Panel A) and India (Panel B). Investments are measured as annual percentage growth in total assets. $K Z$ index is the industry median of U.S. firm-level index, calculated using Baker, Stein, and Wurgler (2003)'s formula. Industry is defined as an SIC 2-digit sector and the median is calculated over the period from 1990 to 2006. FIFA is measured as described in Table 1 , for the last quarter of prior fiscal year. The periods of increase (decrease) in FIFA are from 2005 to 2007 (from 2007 to 2009) for China and from 2003 to 2005 (from 2005 to 2007) for India. 